\title{
HUBUNGAN FAKTOR PROMOSI KESEHATAN TENTANG HIV/AIDS, STIGMA INTERNAL DIRI, DAN DUKUNGAN SOSIAL DENGAN PEMANFAATAN LAYANAN VOLUNTARY COUNSELLING DAN TESTING (VCT) OLEH KELOMPOK LGBT DI KOTA KUPANG
}

\author{
Sitti Hasnah E. Abon ${ }^{1}$, Rafael Paun ${ }^{2}$, Maria M. Dwi Wahyuni ${ }^{3}$, Soleman Landi ${ }^{4}$ \\ ${ }^{1}$ Komisi Perlindungan Anak dan Ibu Kota Kupang \\ ${ }^{2}$ Keperawatan, Poltekes Kemenkes Kupang \\ ${ }^{3-4}$ Epidemiologi dan Biostatistika, FKM Undana
}

Dinyatakan Layak Publikasi :

Kupang, 02 Maret 2019

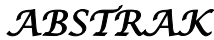

LGBT rentan dengan penularan IMS dan HIV. Sebagai kelompok yang tersembunyi LGBT tetap berkembang dengan pesat, di Kota Kupang tahun 2010 dengan tiga spot sebagai tempat kumpul dengan jumlah yang masih terbatas namun di tahun 2015 terjadi peningkatan tetapi tidak ditunjang dengan kunjungan kelompok LGBT ke layanan VCT. Tercatat sepanjang tahun 2015 sebanyak 18 orang saja yang mau ke layanan VCT. Pemanfaatan layanan VCT sangat penting karena merupakan pintu masuk untuk pencegahan dan perawatan HIV dan AIDS.

Penelitian ini bertujuan untuk mengetahui hubungan faktor promosi kesehatan tentang hiv/aids, stigma internal diri, dan dukungan sosial dengan pemanfaatan layanan voluntary counselling dan testing (VCT) oleh kelompok LGBT Di Kota Kupang. Jenis penelitian adalah mix method yang memadukan metode kualitatif dan kuantitatif, dengan desain Cross Sectional. Populasi penelitian adalah kelompok LGBT yang berjumlah 460 orang. Sampel penelitian sebanyak 210 orang yang di pilih secara random sampling. Analisis yang digunakan univariat, bivariat menggunakan uji chi square dan multivariate menggunakan uji Regresi Logistik Berganda.

Hasil analisis menunjukkan bahwa faktor promosi kesehatan $(\mathrm{p}=0,336>\alpha 0,005)$ dan stigma ( $\mathrm{p} 0,546>$ $\alpha 0,005$ ) tidak berhubungan dengan pemanfaatan layanan VCT kelompok LGBT. Sedangkan faktor dukungan sosial mempunyai hubungan $(\mathrm{p}=0,037<\alpha$ $0,005)$ dengan pemanfaatan layanan VCT oleh kelompok LGBT.
\end{abstract}

Kata kunci : Promosi Kesehatan, Hiv/Aids, Stigma Internal Diri, Dukungan Sosial, Pemanfaatan Layanan Voluntary Counselling Dan Testing (VCT), LGBT

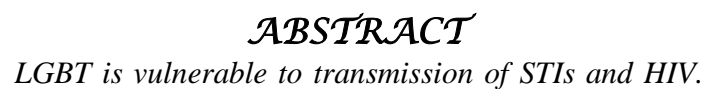
As a hidden group LGBT continues to grow rapidly, in Kupang City in 2010 with three spots as a meeting place with a limited number but in 2015 there was an increase but was not supported by LGBT group visits to VCT services. It was recorded that in 2015 there were only 18 people who wanted to go to VCT services. The use of VCT services is very important because it is the entrance for HIV and AIDS prevention and care.

This study aims to determine the relationship of health promotion factors about HIV / AIDS, internal selfstigma, and social support with the use of voluntary counseling and testing (VCT) services by LGBT groups in Kupang City. This type of research is a mix method that combines qualitative and quantitative methods, with Cross Sectional design. The study population was LGBT groups of 460 people. The research sample was 210 people selected by random sampling. The analysis used univariate, bivariate using chi square test and multivariate using Multiple Logistic Regression tes

The results of the analysis showed that the health promotion factor $(p=0.336>\alpha 0.005)$ and stigma $(p$ $0.546>\alpha 0.005)$ were not related to the utilization of LGBT group VCT services. While the social support factor has a relationship $(p=0.037<\alpha 0.005)$ with the use of VCT services by LGBT groups.

Key words: Health Promotion, HIV / AIDS, Stigma Internal Self, Social Support, Utilization of Voluntary Counseling and Testing (VCT) Services, LGBT

\section{PENDAHULUAN}


Data kasus HIV di NTT sebanyak 1.743 Kasus dan AIDS sebanyak 1.957 Orang. Kota Kupang data HIV dan AIDS sesuai dengan data di KPA Kota Kupang, dari tahun 2000 hingga Desember 2015 sebanyak 811 kasus, dengan rincian HIV 584 kasus dan AIDS 227 kasus, data ini juga termasuk kelompok LGBT. Perkembangan LGBT di Kota Kupang meningkat dari tahun ke tahun, sering dengan perkembangan pola komunikasi dan relasi sosial. Di tahun 2010 baru dijumpai 35 orang namun meningkat tajam di tahun 2015 menjadi 460 orang terjadi peningkatan sebesar 7,6\%. Sepanjang tahun 2015, tiga layanan VCT mampu menerima kunjungan termasuk pengiriman sampel darah sebanyak 9.208 sampel, dalam catatan klinik VCT Sobat RSU W.Z.Yohannes tercatat sepanjang tahun 2015 ada 18 orang atau 3,91\% dari kelompok LGBT yang ikut tes HIV, dan yang terpapar HIV sebanyak 8 kasus dari kelompok gay. Masih kurangnya pemanfaatan layanan VCT oleh kelompok LGBT, hal ini disebabkan karena kelompok LGBT belum menyadari tentang manfaat layanan VCT.

Upaya yang dilakukan pemerintah adalah sesuai dengan Peraturan Menteri Dalam Negeri Nomor 20 tahun 2007 tentang Pembentukan Komisi Penanggulangan AIDS dan Pemberdayaan Masyarakat dalam rangka Penanggulangan HIV dan AIDS di Daerah, sehingga membentukan KPA baik Nasional, Provinsi maupun Kota/Kabupaten. Khusus untuk Kota Kupang pemerintah membuat regulasi bagi pencegahan HIV dan AIDS dan atas inisiatif DPRD Kota membuat Peraturan Daerah No 11 tahun 2013 tentang Pencegahan dan Penangganan HIV dan AIDS di Kota Kupang. Yang diikuti Peraturan Walikota yang isinya antara lain melakukan sosialisasi guna peningkatan pengetahuan mengenai HIV dan AIDS bagi masyarakat umum termasuk kelompok LGBT.

Dukungan pemerintah bagi kelompok LGBT seperti pendanaan untuk pertemuan advocasi, pertemuan peningkatan kapasitas bagi anggota komunitas, terlibat dalam kegiatan Monitoring dan Evaluasi dan untuk upaya pencegahan penularan IMoF juga menjadi Outlet kondom untuk komunitas LGBT. Tersedia tiga layanan VCT di Kota Kupang yakni di Klinik VCT Sobat di R.S.U. Yohannes, Klinik VCT Seroja di RST. Wirasakti dan RS. Bhayangkara di Klinik VCT Turangga dan untuk menunjang tiga layanan tersebut maka tahun 2015 pemerintah Kota Kupang menyediakan sepuluh (10) puskesmas melalui pelatihan bagi tiga (3) orang yang khusus melayani konseling dan testing HIV, yakni petugas analis, Administrasi dan konselor, dengan tujuan banyak pilihan tempat, guna mendekatkan akses VCT maka disiapkan layanan mobile VCT. Namun belum banyak kunjungan dari kelompok populasi kunci terutama kelompok LGBT sehingga perlu untuk diadakan penelitian. Berdasarkan kondisi tersebut maka peneliti tertarik untuk meneliti “ Faktor-faktor yang berhubungan dengan pemanfaatan layanan VCT oleh kelompok LGBT di Kota Kupang".

\section{METODE PENELITIAN}


Jenis penelitian yang digunakan adalah mixd method. Menurut Sugiyono (2011) metode penelitian kombinasi adalah metode penelitian yang menggabungkan antara metode kuantitatif dan metode kualitatif. Desain penelitian yang digunakan adalah Cross Sectional yaitu penelitian yang melihat hubungan antara variabel penyebab dan akibat pada saat bersamaan ( sesaat ). Populasi dalam penelitian ini adalah LGBT di Kota Kupang. Berdasarkan data yang diperolah jumlah LGBT 460 orang (sumber: KPA Kota dan IMoF, 2015). Dengan sampel dalam penelitian ini sebesar 210 orang, dan Informan untuk data kualitatif dipilih dari kelompok LGBT sebanyak 14 responden dari 210 repsonden yang ada. Penelitian ini dilakukan di Kota Kupang, pada Komunitas Independent Man of Flobamora (IMoF) Kupang selama dalam 6 bulan mulai dari Oktober 2016 - Maret 2017. Analisisi yang digunakan adalah regresi logistik sederhana dan berganda ( Kuntoro, 2007).

\section{HASIL DAN PEMBAHASAN}

\section{A. Prevalensi HIV dan AIDS}

Prevalensi merupakan sebuah kesering suatu penyakit atau kondisi terjadi pada sekelompok orang, terutama berkaitan dengan kejadian HIV dan AIDS terutama pada kelompok LGBT sebagai kelompok dengan resiko tinggi. Gambaran mengenai prevalensi HIV dapat dilihat pada Tabel 1.

Tabel 1. Prevalensi HIV dan AIDS pada kelompok LGBT di Kota Kupang Tahun

\begin{tabular}{|c|c|c|c|c|c|c|c|c|c|c|}
\hline \multirow[t]{3}{*}{ Status HIV } & \multicolumn{8}{|c|}{ LGBT } & \multirow[t]{3}{*}{$\mathrm{n}$} & \multirow[t]{3}{*}{$\%$} \\
\hline & \multicolumn{2}{|c|}{ Lesbian } & \multicolumn{2}{|c|}{ Gay } & \multicolumn{2}{|c|}{ Biseksual } & \multicolumn{2}{|c|}{ Transgender } & & \\
\hline & $\mathrm{n}$ & $\%$ & $\mathrm{n}$ & $\%$ & $\mathrm{n}$ & $\%$ & $\mathrm{n}$ & $\%$ & & \\
\hline $\mathrm{HIV}+$ & 0 & 0 & 4 & 2,50 & 2 & 12,5 & 4 & 20,00 & 10 & 4,76 \\
\hline HIV - & 20 & 100,00 & 154 & 97,50 & 14 & 87,5 & 11 & 80,00 & 200 & 95,24 \\
\hline Jumlah & 20 & 100,00 & 159 & 100,00 & 16 & 100,00 & 15 & 100,00 & 210 & 100.0 \\
\hline
\end{tabular}

Sumber data primer diolah tahun 2017

Tabel 1 menggambarkan angka prevalensi HIV atau kejadian HIV pada kelompok LGBT sebesar 4,76\%. Terbanyak dari kelompok Gay sebesar 4 kasus dan Transgender sebesar 4 kasus. Berdasarkan perkiraan WHO terhadap kejadian dari 10 yang positif diperkirakan sebanyak 1.000 lainnya yang sudah positif HIV tetapi belum teridentifikasi, hal ini menimbulkan masalah apabila seorang yang positif memiliki pasangan lebih dari satu dengan pola hubungan seks yang tidak aman atau tidak menggunakan kondom. Ini didukung oleh data Red Cross Thailand pada tahun 2014 ada 8.000-10.000 infeksi baru HIV setiap tahunnya, 40\% berasal dari kalangan gay.

\section{B. Gambaran Promosi Kesehatan HIV dan AIDS, Dukungan Sosial dan Stigma kelompok LGBT di Kota Kupang.}


IGLA Lesbian Health (2013) menyarankan kepada kelompok lesbian untuk tidak hidup sebagai lesbian yang tertutup, untuk menjadi diri sendiri dan untuk dapat berkembang maka kamu membutuhkan beberapa teman dekat yang bisa kamu dapat dengan melalui proses coming out. Ini bukan berarti bahwa kamu harus terbuka kepada semua orang setiap waktu dan dalam setiap keadaan. Berkaitan dengan promosi kesehatan tentang HIV dan AIDS, serta dukungan sosial bagi kelompok LGBT dan stigma yang dialami oleh LGBT dapat dilihat pada Tabel 2.

Tabel 2. Distribusi Promosi Kesehatan HIV dan AIDS, Dukungan Sosial dan Stigma oleh Kelompok LGBT di Kota Kupang Tahun 2017

\begin{tabular}{|c|c|c|c|c|c|c|c|c|c|c|}
\hline \multirow[t]{3}{*}{ Variabel } & \multicolumn{8}{|c|}{ LGBT } & \multirow[t]{3}{*}{$\mathrm{n}$} & \multirow[t]{3}{*}{$\%$} \\
\hline & \multicolumn{2}{|c|}{ Lesbian } & \multicolumn{2}{|c|}{ Gay } & \multicolumn{2}{|c|}{ Biseksual } & \multicolumn{2}{|c|}{ Transgender } & & \\
\hline & $\mathrm{n}$ & $\%$ & $\mathrm{n}$ & $\%$ & $\mathrm{n}$ & $\%$ & $\mathrm{n}$ & $\%$ & & \\
\hline \multicolumn{11}{|l|}{ Promosi kesehatan } \\
\hline Kurang & 12 & 60,0 & 85 & 53,5 & 7 & 46,7 & 2 & 12,5 & 106 & 50,5 \\
\hline Baik & 8 & 40,0 & 74 & 46,5 & 8 & 53,3 & 14 & 87,5 & 104 & 49,5 \\
\hline Jumlah & 20 & 100 & 159 & 100 & 15 & 100 & 16 & 100 & 210 & 100 \\
\hline \multicolumn{11}{|l|}{ Dukungan Sosial } \\
\hline Kurang & 11 & 55,0 & 81 & 50,9 & 2 & 13,3 & 1 & 6,2 & 95 & 45,2 \\
\hline Baik & 9 & 45,0 & 78 & 49,1 & 13 & 86,7 & 15 & 93,8 & 115 & 54,8 \\
\hline Jumlah & 20 & 100 & 159 & 100 & 15 & 100 & 16 & 100 & 210 & 100 \\
\hline \multicolumn{11}{|l|}{ Stigma } \\
\hline Tinggi & 7 & 35,0 & 78 & 49,1 & 8 & 53,3 & 15 & 93,8 & 108 & 51,4 \\
\hline Rendah & 13 & 65,0 & 81 & 50,9 & 7 & 46,7 & 1 & 6,2 & 102 & 48,6 \\
\hline Jumlah & 20 & 100 & 159 & 100 & 15 & 100 & 16 & 100 & 210 & 100 \\
\hline
\end{tabular}

Tabel 2 menunjukkan bahwa 60\% responden dari kelompok lesbian menilai bahwa promosi kesehatan mengenai HIV dan AIDS kurang didapatkan oleh mereka secara rutin, hal ini dapat berkaitan dengan kurang berfungsinya organisasi komunitas lesbian, juga disebabkan karena pola kehidupan lesbian hanya di dalam lingkungan mereka saja, serta media promosi kesehatan masih bersifat umum belum terdistribusi media kesehatan khusus untuk lesbian. Hal yang sama terjadi pada gay dan biseksual, terutama gay dan biseksual yang belum aktif di organisasi komunitas atau belum mendapatkan informasi dari pendidik sebaya dan belum adanya jenis media kie yang khusus buat kelompok LSL membuat semua responden mendapatkan informasi dari media sosial. Namun sebanyak 14 responden $(87,5 \%)$ Transgender mampu mendapatkan dengan baik dukungan informasi melalui kegiatan promosi kesehatan HIV dan AIDS, melalui kegiatan sosialisasi, Internet (google, Facebook), membaca booklet, brosur. Sesuai dengan hasil penelitian dari Murniyati (2015) bahwa secara intens waria mendapatkan informasi karena adanya pendampingan dari LSM.

Dukungan sosial merupakan dambaan setiap manusia yang didapat melalui banyak cara seperti menyapa, memberikan imbalan atau hadiah, membantu dalam bentuk material atau non material. Penelitian ini memberikan gambaran pada tabel 4.6 diatas, lesbian merupakan kelompok yang kurang mendapatkan dukungan sosial sebesar 55\%. Merasa bahwa tidak didukung bukan hanya dirasakan oleh kelompok lesbian tetapi juga dialami oleh kelompok gay 81 responden $(50,9 \%)$ mengakui tidak 
mendapatkan dukungan terutama ketika ke layanan kesehatan dari keluarga, berjumpa dengan $\mathrm{C}^{\mathbf{1}}$ dan menyampaikan isi hatinya sebagai berikut :

........" mungkin mama saya tahu ....mama saya mungkin firasatnya seorang ibu ... memang mama saya tidak nyaman kalau ada laki-laki datang kerumah, langsung menunjukkan sikap yang tidak setuju dan itu dirasakan teman- teman saya ...."... dan keluarga... saya tidak ada yang tahu... semoga keluarga saya baik - baik saja.... Dan saya tidak mempromosikan diri sebagai gay ... ”...

Dukungan sosial yang paling menarik ketika seseorang memilih menjadi bagian dari LGBT adalah datang dari lingkungan keluarga 15 responden $(93,8 \%)$ dari kelompok transgender mendapatkan dukungan baik dari keluarga dan teman komunitasnya. Digambarkan oleh $\mathrm{N}$ seorang Transgender yang bangga dengan dukungan sosial:

... “.. saya dandan pertama kali ketika SMA waktu ikut lomba Waria dan menang, dan sejak itu saya ikut lomba saya bapak duduk didepan, ,...... waktu mau buat payudara.... bapak saya terserah kau saja yang penting kau nyaman......" dilanjutkan bahwa keluarga saya menerima saya apa adanya...." ...saya juga ke gereja pada hari minggu ... Uskup dan Romo juga menerima saya dengan tangan terbuka...Tuhan tidak melihat ..dari penampilan... dari pelacur....atau dari lain - lain .."...(N)

Selain dukungan yang didapat kelompok LGBT lebih banyak berurusan dengan masalah stigma dan diskriminasi. Stigma dan diskiriminasi merupakan momok bagi seluruh masyarakat, bukan hanya dirasakan oleh kelompok LGBT tetapi juga oleh kelompok heteroseksual, kelompok minoritas lainnya. Berkaitan dengan stigma, tabel 4.6 diatas memberikan gambaran bahwa stigma masih dirasakan oleh kelompok LGBT. Transgender merasakan adanya stigma sebesar sebesar 93,8\%. Sebagai seorang transgender $\mathrm{N}$ walaupun mampu adaptasi dengan warga lingkungan sekitar hingga Tokoh Agama, $\mathrm{N}$ mengatakan bahwa stigma bisa diciptakan oleh kita dalam kelompok minoritas itu sendiri. Ungkap N sebagai berikut:

...." Sebenarnya masyarakat itu menerima tapi kembali ke kita banci ini.. bertutur kata dengan baik, berpakaian dengan baik, kalau kita tenang tidak pecicilan.. masyarakat akan menerima kita..." $(N)$

Lesbian merupakan kelompok yang merasakan paling rendah atau tidak adanya stigma dirasakan oleh Lesbian sebesar 65\%. Hal ini disebabkan lesbian diterima dengan baik oleh lingkungan tempat tinggal mereka dan tempat kerja mereka. ketika FGD dengan empat orang mengatakan :

..."...kalau di lingkungan ini lasiana cukup menerima... ... bos juga kasih jdi anak muda terima, $R T$ juga tidak complain... " $\left(M^{2}, B, I, F\right)$

\section{Gambaran Pemanfaatan Layanan VCT kelompok LGBT di Kota Kupang}

Berkaitan dengan pemanfaatan layanan VCT kurang dari tiga (3) kali dalam setahun yang paling tinggi adalah Gay sebesar 66,7\%. Hal ini karena mendapatkan layanan mobile VCT sehingga intensitas ke layanan VCT berkurang, ditunjang oleh organisasi gay waria lelaki seks lelaki tingkat Nasional bahwa Layanan kesehatan 
seksual serta layanan konseling dan testing HIV yang bersahabat bagi komunitas gay, waria dan LSL lain juga sangat terbatas yang menimbulkan keengganan dari komunitas untuk datang memeriksakan kesehatan seksualnya serta untuk melakukan konseling dan testing HIV.

Tabel 3. Distribusi Pemanfaatan Layanan VCT oleh kelompok LGBT di Kota Kupang Tahun 2017

\begin{tabular}{|c|c|c|c|c|c|c|c|c|c|c|}
\hline \multirow[t]{3}{*}{ Pemanfaatan Layanan VCT } & \multicolumn{8}{|c|}{ LGBT } & \multirow[t]{3}{*}{$\mathrm{n}$} & \multirow[t]{3}{*}{$\%$} \\
\hline & \multicolumn{2}{|c|}{ Lesbian } & \multicolumn{2}{|c|}{ Gay } & \multicolumn{2}{|c|}{ Biseksual } & \multicolumn{2}{|c|}{ Transgender } & & \\
\hline & $\mathrm{n}$ & $\%$ & $\mathrm{n}$ & $\%$ & $\mathrm{n}$ & $\%$ & $\mathrm{n}$ & $\%$ & & \\
\hline$<$ dari 3 kali setahun & 13 & 65,0 & 106 & 66,7 & 6 & 40,0 & 7 & 43,8 & 132 & 62,9 \\
\hline 4 kali setahun & 7 & 35,0 & 53 & 33,3 & 9 & 60,0 & 9 & 56,2 & 78 & 37,1 \\
\hline Jumlah & 20 & 100 & 159 & 100 & 15 & 100 & 16 & 100 & 210 & 100 \\
\hline
\end{tabular}

Cerita J ketika jumpa di tempat kos bahwa;

..." beta ni tahu vet karena petugas kesehatan yang suruh... jadi baru dua kali..tapi ini rencana harus rajin..." (J)

Kelompok lesbian sebesar 65\% kurang dari tiga kali ke layanan VCT disebabkan karena kurang berperannya organisasi komunitas sehingga promosi mengenai kesehatan dan terutama mengenai layanan VCT belum intens dilakukan. Sedangkan kelompok yang paling banyak mengakses layanan VCT lebih dari tiga hingga empat kali dalam setahuan yakni biseksual sebesar $60 \%$.

\section{Hubungan Promosi Kesehatan, Dukungan Sosial dan Stigma dengan Pemanfaatan Layanan VCT oleh Kelompok LGBT.}

Untuk mengetahui faktor yang berhubungan promosi kesehatan, dukungan sosial dan stigma dengan pemanfaatan layanan VCT oleh kelompok LGBT dapat dilihat pada Tabel 4. Promosi kesehatan memiliki tujuan terutama yang berkaitan dengan HIV dan AIDS, adalah untuk meningkatkan pengetahuan dan meningkatkan keterampilan pencegahan penularan HIV, dapat dilihat pada tabel 4.15.

Tabel 4. Hubungan Promosi Kesehatan dengan Pemanfaatan Layanan VCT oleh kelompok LGBT di Kota Kupang Tahun 2017

\begin{tabular}{|c|c|c|c|c|c|c|c|c|}
\hline \multirow[t]{3}{*}{ Variabel } & \multicolumn{4}{|c|}{ Pemanfaatan Layanan VCT } & \multirow{2}{*}{\multicolumn{2}{|c|}{ Total }} & \multirow[t]{3}{*}{$\mathrm{p}$} & \multirow[t]{3}{*}{$\mathrm{RP}$} \\
\hline & \multicolumn{2}{|c|}{$\begin{array}{l}<3 \text { kali } \\
\text { tahun }\end{array}$} & \multicolumn{2}{|c|}{$\begin{array}{l}>3 \text { atau } 4 \text { kali/ } \\
\text { tahun }\end{array}$} & & & & \\
\hline & $\mathrm{n}$ & $\%$ & $\mathrm{n}$ & $\%$ & $\mathrm{n}$ & $\%$ & & \\
\hline \multicolumn{9}{|l|}{ Promosi Kesehatan } \\
\hline Kurang & 70 & 33,3 & 36 & 17,1 & 106 & 50,5 & 0,336 & 1,11 \\
\hline Baik & 62 & 29,5 & 42 & 20,0 & 104 & 49,5 & & \\
\hline Jumlah & 132 & 62,9 & 78 & 37,1 & 210 & 100,0 & & \\
\hline
\end{tabular}

Sumber data primer diolah tahun 2017

Hasil penelitian diketahui 77 responden $(33,3 \%)$ yang mengunjungi layanan VCT kurang dari tiga kali setahun menilai kurang mendapatkan informasi mengenai HIV dan AIDS, namun 36 responden $(17,1 \%)$ walaupaun kurang mendapatkan informasi mengenai HIV dan AIDS tetapi memutuskan untuk ke layanan VCT 
sebanyak lebih dari tiga kali setahun. Sebanyak 62 responden $(29,5 \%)$ yang mendapatkan promosi mengenai HIV dan AIDS dengan baik tetapi memiliki dorongan ke layanan VCT kurang dari tiga kali setahun, tetapi 42 responden (20\%) mendapatkan promosi mengenai HIV dan AIDS dan layanan VCT secara baik dapat memanfaatkan layanan VCT sebanyak tiga kali setahun. Responden yang mendapatkan promosi mengenai HIV dan AIDS melalui media Internet, booklet, dan stiker. Untuk melihat tingkat kemaknaan antara kedua variabel dilakuan uji statistik diperoleh tingkat kemaknaan $(\mathrm{p}=0,336)$ artinya nilai ini lebih besar dibandingkan $\alpha$ $0,005(\mathrm{p}=0,336>\alpha 0,005)$. Dengan demikian tidak ada hubungan antara promosi kesehatan dengan pemanfaatan layanan VCT kelompok LGBT.

Hasil rasio prevalensi Promosi kesehatan dengan pemanfaatan layanan VCT sebesar 1,11 memiliki artinya bahwa kelompok LGBT yang menilai promosi kesehatan kurang akan memiliki resiko sebesar 1,11 kali untuk mengunjungi layanan VCT kurang dari tiga kali dalam setahun. Promosi kesehatan tidak hanya mengaitkan diri pada peningkatan pengetahuan, sikap dan perilaku kesehatan saja, tetapi juga meningkatkan atau memperbaiki lingkungan (fisik dan non-fisik) dalam rangka memelihara dan meningkatkan kesehatan masyarakat. Hal ini juga terlihat dari angka kunjungan ke layanan VCT oleh kelompok LGBT selama tahun 2015 sebanyak 18 orang, promosi kesehatan baik mengenai HIV dan AIDS atau juga tentang layanan VCT dan manfaat layanan VCT belum mampu di lakukan dengan berulang - ulang untuk merubah perilaku kelompok LGBT, ataukah promosi kesehatan oleh petugas kesehatan atau penjangkau mengenai layanan mobile VCT. Hal lainnya media promosi yang digunakan masih bersifat umum, belum bersifat khusus pada kelompok LGBT. Hasil wawancara R memberikan gambaran sebagai berikut :

... “..informasi kesehatan yang dilakukan memang belum rutin karena pertemuan kelompok jarang ada, memang ada informasi HIV dan AIDS di face book, tetapi mengenai tempat layanan VCT belum rutin di kasih tahu... responden sepakat bahwa media informasi masih bersifat umum belum bersifa khusus bagi kelompok mereka.."

Dukungan sosial sebagai dukungan atau bantuan yang berasal dari orang lain seperti orang tua, teman, tetangga, teman kerja dan orang- orang lainnya, terlihat dalam Tabel 5.

Tabel 5. Hubungan Dukungan Sosial dengan Pemanfaatan Layanan VCT oleh kelompok LGBT di Kota Kupang Tahun 2017

\begin{tabular}{|c|c|c|c|c|c|c|c|c|}
\hline \multirow[t]{3}{*}{ Variabel } & \multicolumn{4}{|c|}{ Pemanfaatan Layanan VCT } & \multirow{2}{*}{\multicolumn{2}{|c|}{ Total }} & \multirow[t]{3}{*}{$\mathrm{p}$} & \multirow[t]{3}{*}{$\mathrm{RP}$} \\
\hline & \multicolumn{2}{|c|}{$<3 \mathrm{kali} /$ tahun } & \multicolumn{2}{|c|}{$\begin{array}{l}>3 \text { atau } 4 \text { kali/ } \\
\text { tahun }\end{array}$} & & & & \\
\hline & $\mathrm{n}$ & $\%$ & $\mathrm{n}$ & $\%$ & $\mathrm{n}$ & $\%$ & & \\
\hline Dukungan Sosial & & & & & & & & \\
\hline Kurang & 67 & 31,9 & 28 & 13,3 & 95 & 45,2 & 0,037 & 1,25 \\
\hline Baik & 65 & 31,0 & 50 & 23,8 & 115 & 54,8 & & \\
\hline Jumlah & 132 & 62,9 & 78 & 37,1 & 210 & 100,0 & & \\
\hline
\end{tabular}

Sumber data primer diolah tahun 2017 
Berkiatan dengan dukungan sosial, sebanyak 67 responden ( 31,9\%) merasa bahwa kurang mendapatkan dukungan dari lingkungan sehingga memilih untuk berkunjung ke layanan VCT kurang dari tiga kali dalam setahun, 28 responden $(13,3 \%)$ merasa kurang mendapatkan dukungan sosial tetapi tetap berusaha ke layanan VCT sebanyak tiga sampai empat kali dalam setahun, sebanyak 65 responden ( $31 \%$ ) yang memiliki dukungan sosial yang baik dari pasangan, petugas kesehatan tetapi memilih untuk kurang dari tiga kali ke layanan VCT, berbeda dengan 50 responden $(23,8 \%)$ memiliki dukungan sosial yang baik dari keluarga, pasangan tetap, petugas lapangan, dan teman sebaya memiliki kesempatan mengunjungi layanan VCT sebanyak tiga sampai empat kali dalam setahun. Hasil penelitian menggambarkan nilai kemaknaan sebesar $\mathrm{p}=0,037$, artinya nilai ini lebih kecil dari nilai $\alpha 0,005(\mathrm{p}=0,037<\alpha 0,005)$. Dengan demikian ada hubungan dukungan sosial dengan pemanfaatan layanan VCT oleh kelompok LGBT. LGBT yang kurang mendapatkan dukungan sosial akan memiliki resiko sebesar 1,25 kali mengunjungi layanan VCT kurang dari tiga kali setahun. Hasil wawancara pada R seorang biseksual sebagai berikut :

“... walaupun orang tua tidak dan kakak saya tidak tahu keadaan saya, tetapi saya mendapatkan dukungan dari sepupu... kami sejak kecil main sama-sama, jadi waktu jadi seperti begini dia juga saya kasih tahu, dia kasih ingat untuk selalu jaga kesehatan, jangan sembarang...." $(R)$

Stigma dan diskiriminasi merupakan situasi yang tidak menyenangkan dan sebagai faktor yang menghambat bagi kelompok LGBT, hasil penelitian mengenai stigma dapat dilihat dalam Tabel 6.

Tabel 6. Hubungan Stigma dengan Pemanfaatan Layanan VCT oleh kelompok LGBT di Kota Kupang tahun 2017

\begin{tabular}{|c|c|c|c|c|c|c|c|c|}
\hline \multirow{3}{*}{ Variabel } & \multicolumn{4}{|c|}{ Pemanfaatan Layanan VCT } & \multirow{2}{*}{\multicolumn{2}{|c|}{ Total }} & \multirow{3}{*}{ PValue } & \multirow{3}{*}{$\mathrm{RP}$} \\
\hline & \multicolumn{2}{|c|}{$<3 \mathrm{kali} /$ tahun } & \multicolumn{2}{|c|}{$>3$ atau 4 kali/ tahun } & & & & \\
\hline & $\mathrm{n}$ & $\%$ & $\mathrm{n}$ & $\%$ & $\mathrm{n}$ & $\%$ & & \\
\hline \multicolumn{9}{|l|}{ Stigma } \\
\hline Tinggi & 70 & 33,3 & 38 & 18,1 & 108 & 51,4 & 0,546 & 1,06 \\
\hline Rendah & 62 & 29,5 & 40 & 19,0 & 102 & 48,6 & & \\
\hline Jumlah & 132 & 62,9 & 78 & 37,1 & 210 & 100 & & \\
\hline
\end{tabular}

Hasil penelitian menunjukkan bahwa sebanyak 70 responden atau sebesar 33,3\% mengatakan bahwa masih tingginya stigma masyarakat sehingga responden memutuskan untuk mengunjungi layanan VCT tetapi kurang dari tiga kali dalam setahun. Terdapat 38 responden atau $18,1 \%$ merasakan juga tingginya stigma tetapi tetap berkujung ke layanan VCT tiga hingga empat kali setahun, 62 responden atau 29,5\% menilai tidak ada stigma masyarakat atau rendah stigma masyarakat tetapi kurang memanfaatkan layanan VCT, namun sebanyak 40 repsonden atau 19\% yang menilai stigma masyarakat rendah dan memanfaatkan layanan VCT sebanyak tiga hingga empat kali dalam setahun. Nilai kemaknaan dari stigma ini sebesar $\mathrm{p}=0,546$ artinya lebih besar dari $\alpha 0,005$ ( $\mathrm{p}$ 0,546 $>\alpha 0,005$ ) dengan demikian tidak ada hubungan stigma dan pemanfaatan layanan VCT oleh kelompok LGBT. walaupun 
stigma membawa dampak buruk sehingga sering terjadi pengucilan, pengusiran bahkan kekerasan tetapi tidak memberikan efek pada kelompok LGBT karenanya kelompok LGBT tetap mengakses layanan VCT walaupaun sebanyak 62,9\% memilih kurang dari tiga kali dalam setahun. Hasil Rasio Prevalensi Stigma dengan pemanfaatan layanan VCT menunjukkan bahwa responden yang memiliki stigma yang tinggi memiliki resiko sebesar 1,06 kali atau sebesar 1 kali untuk mengunjungi layanan VCT kurang dari tiga kali dalam setahun. Mendapatkan stigma namun tetap dibutuhkan sulit untuk dibayangkan namun dirasakan kelompok ini, ungkapan hari Ibu A seorang transgender, bahwa:

...".. memang masih ada stigma tetapi apakah menjadi masalah bagi orang lain, jika kami dipandang dari segi yang positif maka akan positif, memangnya waria ini salah ? salahnya dimana? memangnya kami pakai pakaian perempuan itu menjadi masalah ...padahal kami lgbt ini baik, kami ini buat baik kami bisa jadi motivator pada orang lain, inspirasi buat orang lain... sehingga perlu ada kerja sama karena kita tidak ada yang sempurnah..." dilanjutkan soal penerimaan masyarakat, di kota ini ada kemunafikan lihat waria sonde suka, lihat lgbt sonde suka tapi kalau malammalam cari ketong.."

Walaupun sama- sama dilingkaran LGBT namun berbeda secara fisik membuat kelompok gay dan biseksual menceritakan bahwa :

...".. lingkungan tempat kami tinggal ini seputaran TDM tahu bahwa kami belok.. tapi mereka menerima kami apa adanya.. tegur kami seperti biasa.. kami punya pemilik kos juga tahu ... kalau yang datang bertamu di sini model sama..tapi dong biasa sa...".. (J dan AC)

\section{E. PENUTUP}

Berdasarkan hasil penelitian dapat disimpulkan bahwa hanya faktor Dukungan sosial yang berhubungan dengan pemanfaatan layanan VCT oleh Kelompok LGBT. Hasil penelitian ini memberikan gambaran penularan HIV dan AIDS makin meningkat terutama pada kelompok resiko tinggi, untuk itu perlu upaya untuk menanggulanginya yaitu untuk meningkatkan pemanfaatan layanan VCT pemerintah harus meningkatkan kualitas layanan VCT termasuk sarana dan prasarannya. Dan perlu menambah jumlah layanan VCT sehingga masyrakat memiliki kesempatan untuk memilih tempat layanan VCT.

\section{DAFTAR PUSTAKA}

Azwar Saifuddin, 1998, Sikap Manusia: Teori dan Pengukurannya, Yogyakarta, Liberty.

Buchari Lapau, Metode Penelitian Kesehatan, Jakarta, Yayasan Pustaka Obor Indonesia, 2013

http://jurnal.fk.unand.ac.id, Vicca Rahmayani, Akmal M.Hanif, Susila Sastri Jurnal Kesehatan Andalas. 2014; 3(2) 
http://jurnal.pasca.uns.ac.id, Ketut Indra Purnomo, Bhisma Murti, Putu Suriyasa Jurnal Magister Kedokteran Keluarga Vol 1, No 1, 2013 (hal 49-56)

Ilga.org/health/ILGA_Lesbians_Health_Myths_Realities_Indonesia.

Jurnal Kesehatan Reproduksi Vol. 5 No 1, April 2014 : 49-57 Mujiati dan Julianty P (2013), Faktor Persepsi dan sikap dalam Pemanfaatan VCT oleh kelompok berisiko tinggi di Kota bandung tahun 2013

http://ejournal-s1.undip.ac.id/index.php/jkm, Mustafidatun Najah, hubungan beberapa faktor dengan perilaku seksual berisiko ims pada waria binaan pondok pesantren (ponpes) waria senin- kamis yogyakarta tahun 2015 volume 3, nomor 3, april 2015 (issn: 2356-3346)

Jurnal psikologi terapan, yogestri rakhmahappin dan adhyatman prabowo, kecemasan sosial kaum homoseksual gay dan lesbian ( 2014) fakultas psikologi uniersitas muhamadyah malang, issn: 2301-8267 vol. 02, no.02, januari 2014.

Jurnal Kesehatan Reproduksi Vol. 4 No 3, Desember 2013 : 153 - 160 , Mujiati, Sugiharti, Bryan Mario Isakh (2013), gambaran pelaksanaan layanan voluntary counseling and testing (vet) dan sarana prasarana klinik vet di kota bandung tahun 2013, Pusat Teknologi Intervensi Kesehatan, Badan Litbangkes, Kemenkes RI,

Rotua Suriany Simamora, alternatif kebijakan perilaku penggunaan kondom untuk pencegahan hiv pada pekerja seks waria di lokalisasi gor kota bekasi tahun 2014, ISSN 2337-6686, issn-1 2338-3321 jurnal ilmiah widya, volume 2 nomor 3 agustus-oktober 2014

Jurnal college of Public Health Sciences, Chulalongkorn University, Bangkok, Thailand (2016) , Myo Zin Oo. Alessio Panza, Sexual History and Satisfaction of services Related to HIV and AIDS among Men Having Sex With Men (MSM) in Mandalay, Miyanmar. 